JCMS

2,1

6

\title{
Due diligence in capital markets
}

\author{
Mervyn King \\ Johannesburg, South Africa
}

In capital markets long-term debt, equities or securities are bought and sold

Through this mechanism, the money of savers which are held by financial institutions is put to long-term productive use by companies or governments. There are regulators who oversee how these markets are operating and the institutions who are investing their ultimate beneficiaries' money in these capital markets.

There are both primary and secondary capital markets. In the primary markets, new share issues or bonds are sold to asset owners or institutions holding the money of investors and savers. In the secondary market existing bonds or equities are sold among traders or investors. A secondary market is important because it encourages investments into primary markets. This is so because the initial capital market investor knows that it is able to sell the equities or bonds acquired by it if circumstances call for such disposal.

In the acquisition of shares the members of the capital market will acquire equity in the companies who have issued those shares whereas acquiring a bond issued by a company the capital market investor becomes a creditor of the company.

It will be seen that companies in raising money have to make a decision whether they are going to do so by way of equity or bonds. If by equity then the company's debt is not increased but if by bonds the company's debt is increased. From the investor's perspective, a bond is less risky because it will rank ahead of shares on bankruptcy. On the other hand, the shares could give the investor a higher return by way of an increase in the share price and increasing dividends.

In this paper, I want to focus on the financial institutions in the capital markets acquiring either equity or bonds issued by companies. Usually when a company issues a bond with a particular coupon the financial institutions in the capital market bid for the bond. The successful bidder obviously acquires the bond and becomes a creditor of the company. In acquiring either shares or bonds issued by a company the financial institution in the capital market owes a duty of care to its ultimate beneficiaries to ensure that it does a due diligence on the company and that it is going to not only survive but thrive, at least for the duration of the bond, or in the case of equity it may be an investment by a pension fund and the intention may be to dispose of it in the longer term.

Until towards the end of the twentieth century, a due diligence consisted only of a financial due diligence. This is because the success of the business of a company was seen through a financial lens with the tests being increasing monetary bottom line profit, increased share price and increased dividend payments. There was this focus because of the concept of the primacy of the shareholder. Success as suggested in the UK Companies Act is the success of the business of the company in the best interests of the shareholder while having regard to other environmental, social and governance factors.

There is a realisation in the world that we are in a resource constrained one but with increasing population. At present, we have approximately $7.4 \mathrm{bn}$ people on the planet and by

Journal of Capital Markets Studies

Vol. 2 No. 1, 2018

pp. 6-8

Emerald Publishing Limited

2514-4774

DOI 10.1108/JCMS-07-2018-014

(C) Mervyn King. Published in the Journal of Capital Markets Studies. Published by Emerald Publishing

Limited. This article is published under the Creative Commons Attribution (CC BY 4.0) licence. Anyone may reproduce, distribute, translate and create derivative works of this article (for both commercial and non-commercial purposes), subject to full attribution to the original publication and authors. The full terms of this licence may be seen at http://creativecommons.org/licences/by/4.0/legalcode 
2045 the estimate is that we will have another $2 \mathrm{bn}$ people on the planet. It is clear that there will be an increased demand for product but with declining natural assets which have been used faster than nature has been regenerating them. Consequently to carry on business as usual is no longer an option.

The consequence has been to change the mindset of the boards of companies to create a business model which will have a positive impact on the three critical dimensions for sustainable development, namely the economy, society and the environment. These three dimensions are interdependent or integrated, as stated in the preamble to the United Nations Sustainable Development Goals of April 2015.

In 2009 at the UN Headquarters in Geneva, IFAC in a meeting held under Chatham House Rules, said that it is clear that financial reporting although critical is no longer sufficient, because an analysis of the market value of companies listed on major stock exchanges around the world showed that only 20 per cent of the market cap was made up of additives in a balance sheet according to financial reporting standards, the other 80 per cent was intangible assets such as strategy, reputation, sustainability, supply chain issues, legitimacy of operations, etc. In order to report on the balance of the value of market cap sustainability reporting was developed. At that historic meeting, I was the chairman of the Global Reporting Initiative and was able to say that sustainability reporting, without the numbers, was meaningless. But I went further, however, by saying that to report in two silos, financial report and sustainability report, was divorced from reality because companies do not operate on that basis.

They operate on a basis that the sources of value creation, or the six capitals as set out in the framework of the International Integrated Reporting Council (IIRC), together with the relationships between the company and its stakeholders are integrated 24/7.

One of the drivers of an integrated approach to strategy and reporting has been responsible investment. Responsible investment requires institutions to enquire as to whether a company has done an integrated report, if not, why not? Has it done a sustainability report, if not, why not? Has it got a supply chain code of conduct? Has that supply chain been monitored? Does the company know what is happening in its supply chain? The reason for all this is that asset owners have learned that a financial due diligence can be done on a company before investing in its equity or its bonds but something can happen to one of its intangible assets, for example reputation, or in the supply chain, such as the use of child labour, which can destroy up to 60 per cent of value on a stock exchange within a few days. Consequently financial institutions in capital markets, before investing their ultimate beneficiaries' moneys in either an equity or bond issue by a company today have to do a completely different due diligence. They have to enquire as to the nature of the company's business model? Is it one that will have a positive impact on the three dimensions for sustainable development? If not what is the value creation strategy of the company to endeavour to eradicate or ameliorate the negative impacts on those three critical dimensions, particularly societal and environmental.

Consequently, a due diligence of companies has become all embracing-diligently studying the additives in the balance sheet, the company's business model and the intangible assets. A financial due diligence is well-known but a due diligence in the long-term value creation business model of a company has to indicate that it is one which is sustainable in a resource constrained world. It is, in this context, that the IIRC was formed once it was accepted by the great standard setters and reporting institutions that financial reporting alone was not sufficient. It follows that a due diligence on only the financials will not be sufficient.

In conclusion, the institutions participating in capital market transactions involving company shares or bonds have to exercise great care in their due diligence before investing their ultimate beneficiaries' money. The revolutionary immensity of integrated thinking
Due diligence in capital markets 
JCMS

2,1

8

as advocated in the IIRC Framework is in the creation of the company's business model. It drives the board to think of the six capitals, financial, manufactured, human, natural, intellectual and social which includes the relationships between the company and its stakeholders in creating that business model. In finalising the value creation strategy, the board will also consider the outcomes of its products and not only the activities inside the business model or the output of the company itself, namely its product.

Financial institutions in capital markets may well need people other than auditors to assist them in doing a due diligence which covers all the risks associated with the intangible assets making up 80 per cent of a company's market value before investing their beneficiaries' money in the company's equity or bonds. 